$$
\text { BA-16 } \quad 62^{3}
$$

\title{
AGENCY FOR INTERNATIONAL DEVELOPMENT
}

\author{
REVIEW AND DOCUMENTATION \\ of the \\ PRIVATE ENTERPRISE PROGRAM IN AFGHANISTAN, 1964-74
}

(AID Projects 087 and 16 )

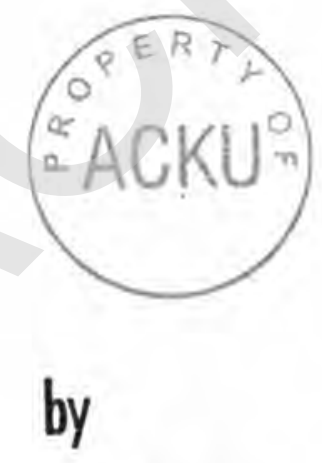

Cornelius H. Zondag

Private Enterprise Officer

USAID/Afghanistan

June 30, 1974 


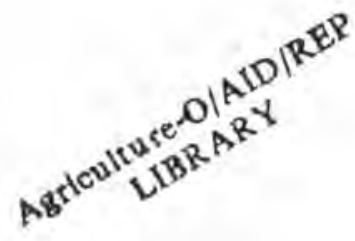

Agriculture-O/AID/REP

LIBRAR Y

AGENCY FOR INTERNATIONAL DEVELOPMENT

REVIEW AND DOCUMENTATION

of the

PRIVATE ENTERPRISE PROGRAM IN AFGHANISTAN, 1964-74

(AID Projects 087 and 116)

by

Cornelius H. Zondag Private Enterprise Officer

USAID/Afghanistan

Kabul, Afghanistan

June 30, 1974 


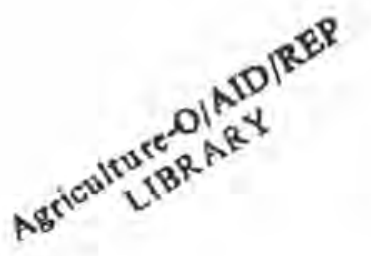

Agriculture-Q/AID/REP

LIBRARY

\section{CONTENTS}

$\underline{\text { Page Number }}$

Summary Review

i-iv

I. Introduction

1

II. The Overall Sector Problem 5

$\begin{array}{ll}\text { III. Project Objectives } & 7\end{array}$

IV. Project Phasing 8

V. Historical Review of the Private Enterprise Project 9

A. Phase One 9

1. The Major Project Components 9

a. Industrial Development $\quad 9$

b. Export Promotion - The Afghan 20

Karakul Institute

c. Promotion of Tourism 25

2. Significant Problems During the First 26 Phase

3. Multilateral Aspects 29

B. Phase Two 30

1. The Major Project Components 30

a. Industrial Policy Formulation $\quad 30$

b. Industrial Extension $\quad 35$ 
Page Number

c. Institutional Development 38

d. Research 41

2. The Mining Sector 43

3. Significant Problems During the Second 44 Phase

VL Results $\quad 46$

VII. Socio-Political Benefits 52

VIII. Profile of the Investors 53

IX. Critical Comment - The Economic Arguments 56

X. Project Inputs and Causality 58

XI. The Role of the Contractors 60

XII. Project Termination $\quad 62$

$\begin{array}{ll}\text { XIII. Conclusion } & 65\end{array}$

\section{APPENDIX}

Annex A; The Role of the Private Sector in the Early 66 Development of the Afghan Economy

Annex B: A Case Study in Afghan Investment Procedure 83

Annex C: Comparison of Foreign and Domestic Private $\quad 87$ Investment Laws of 1345 and 1353

Annex D: Afghanistan's Mining Sector $\quad 112$

Annex E: Active Projects under the 1967 Private Invest- 118 ment Law

Annex F: External Assistance to Afghanistan, 1963-73 


\section{SUMMARY REVIEW}

1. USAID experience in Afghanistan would seem to indicate that private industrial development projects, especially if directed towards the development of the agribusiness or export sector, can make a significant contribution to economic and social development as well as to achieving an increase and better distribution of urban and rural income. Afghanistan provides a dramatic test case for this point of view because intermittently a private industry and public sector industry approach was tried to accelerate economic development, the latter generally with disastrous results, which in a negative way would seem to confirm the merits of the former, (Section I).

2. Section II of the "Review" discusses briefly the more general sector problems in bringing about economic and industrial development in a tribal society. Quite often such a society tends to be extraordinarily resistant and indeed hostile to the unifying political discipline required for nation building. Thus, insidious opposition by certain segments of the Establishment or leftist groups are to be reckoned with as potential problems in developing projects of this type, since such projects tend to have a delayed socio-political impact.

3. The project's broader objectives are stated in Section III. Initially they were defined as developing agribusiness industry for export as well as to increase commodities for local consumption in order to save foreign exchange. Subsequently, these objectives were broadened to include certain social aspects which occur in the process of modernization. More narrowly defined, the project remained centered on making an impact on increasing rural and urban income through the development of agribusinesses, using domestic raw materials for export, combined with an element of soundly conceived import substitution.

4. The Project was carried out in two different stages or phases, with the help of two different contractors. Phase One, stressing the promotional aspects such as the development of a proper investment climate for the creation of new industries, ran from 1964-1970. Phase Two, involving largely a change of emphasis so as to put more stress on institution building and the development of industrial policy, continued from 1971-1974, (Section IV). 
5. Section V describes the project's history during its entire period. It discusses the major developments during the first phase, namely (1) the fact that the government became disenchanted with the excessive drain of the newly created public sector industries on the national budget which resulted in a shift towards the private sector through the promulgation of the 1967 Foreign and Domestic Private Investment Law; (2) how the initial project emphasis was changed from the preparation of feasibility studies to the creation of a more attractive investment climate initially aimed at attracting the domestic investor with the expectation-which was fulfilled-that once the domestic investor was happy the foreign investors would follow, and (3) what was done in the area of institutional development in support of the newly created private industrial establishments.

Two sub-projects during Phase One, were more directly concerned with the strengthening of Afghanistan's foreign exchange earnings through the improvement of the Afghan karakul fur industry and the promotion of tourism. Particularly in the case of the karakul fur industry, the methodology followed is interesting since partly as a result of some organizational and policy changes, including the establishment of an independent, co-operative Afghan Karakul Institute, income from karakul pelts increased from about $\$ 9$ million in $1967 / 68$ to some $\$ 17$ million in 1972 .

Significantly, through the cooperative approach, part of these increased foreign exchange earnings were translated into much higher prices to the karakul producers at the grass roots level. Likewise, an impact-admittedly minor-was made in the promotion of tourism in Afghanistan which subsequently developed from an almost zero base into a $\$ 10$ million a year industry.

The discussion of Phase One ends with a brief reference to the problems, mostly of an administrative and political nature, in carrying out the project, as well as with an explanation of how the project was able to generate multilateral support through acting as a catalyst or limited supporter for bigger ventures to be financed by other donors.

Phase Two of the Project centers around the project's subsequently changed emphasis in the direction of industrial policy formulation, the development of industrial extension services and 
fur ther institutional development in support of the newly created private industries. Three institutions originally established in Phase One, the Investment Committee, the Secretariat and the Investment Advisory Center, were strenghthened, although the latter two were subsequently merged into the Investment Promotion and Development Department of the Ministry. Two new institutions, the Industrial Development Bank and the Afghan Association of Private Industries, were established.

Efforts to encourage the development of industrial policy took several forms, such as extensive research in developing a proposed new tariff and an agribusiness emphasis, the preparation of drafts for the modified investment law and detailed implementing regulations, proposals for research and policy making units within the Ministry, and contributions to various five year and annual plans stressing industrial policy.

After a brief discussion of the project's limited involvement in Afghanistan's mineral and petroleum sector, the historical review ends with a discussion of some significant problems during the Second Phase which resulted largely from a tendency on the part of the government to place renewed emphasis on guidance and control of the private industrial sector. In this connection, it also discusses the changes made-both favorable and unfavorable-by the new 1974 Foreign and Domestic Private Investment Law which was promulgated after the fall of the Monarchy and the establishment of the Republic of Afghanistan.

6. Section VI refers to the project's achievements as evidenced by the creation of about one hundred new private industries involving a total investment of about $\$ 15$ million equivalent as well as the creation of some seven thousand new industrial jobs, all supported by the institutional development as mentioned under (5) above.

About thirty percent of these industries are export oriented while some twenty were started with the help of foreign investment, either one hundred percent or in conjunction with Afghan investors.

7. Some of the socio-political benefits derived from the project are discussed briefly in Section VII, mainly in terms of the changes brought about in a traditional society on the eve of modernization. 
8. The "Review" (Section VIII) tries to provide some insight into the make-up of the Afghan investors, what type of men they were and what motivated them to invest in industry. By and large, the investors were either bazaar merchants or their sons who had finished the university, most of them with a good sense of markets but with limited managerial capability. Although they obviously were interested in making money, pecuniary motives were not the only ones to make them act.

9. Section IX addresses some recent criticism of the program by an American Professor in "monetarist" terms, implying that the promotional aspects embodied in the Investment Law could be counterproductive in the long run because of increased imports or higher domestic prices. It appears, however, that such comments were based on erroneous observations, and perhaps too much of a textbook approach.

10. In discussing results, it is necessary to relate what was achieved not only to project inputs, but also to "causality" i.e., to what extent the technical assistance provided made a difference of significant proportion. Section X addresses this subject matter, as it relates the various contributions from AID, other bilateral or multilateral donors and the government of Afghanistan to ultimate success.

The final sections (XI and XII) describe some of the internal administrative difficulties in carrying out the Project as well as how and why it was ended, followed by a conclusion (XII) - in cost/benefit terms - that both on its own merits as well as on the basis of a comparison with other aid efforts in Afghanistan, the project was quite effective in pursuing the established goals and objectives.

Notes:

1. Exchange rates: At this writing the exchange rate for the Afghani is Afs. 59.00 to one U. S. dollar. During the period of the Review, the exchange rate has fluctuated between 51 and 85 Afghanis per dollar.

2. The Afghan calendar year runs from March 21 to March 20 .

3. The Afghan calendar starts with the move of Mohammad from Mecea to Medina, so the current Afghan year is 1353. 


\section{A REVIEW AND DOCUMENTATION \\ of the}

PRIVATE ENTERPRISE PROGRAM IN AFGHANISTAN, 1964-74

\section{INTRODUCTION}

The purpose of this report is twofold. First, it constitutes an attempt to document the history and results of a private enterprise program which operated in Afghanistan from 1964-1974 and which was considered to be very successful. Second, it supports the view that in a very underdeveloped setting, the private sector can make more of a contribution to economic development than we often believe to be possible.

While the latter statement may sound redundant to some, as may be noted from the contents of this report, its truth is not always reflected in the actions and convictions of policy makers and economic development planners. Even if they accept the idea intellectually, they often seem to reject it almost subconsciously because of their normal inclination to visualize foreign aid mostly in terms of government to government programs.

The problem is compounded further by the fact that the concept of "private enterprise", while officially supported in statements by a great many prominent policy makers in the United States and other developed countries, tends to have relatively few backers within the foreign aid bureaucracies of the various donor nations. Contrary to "agriculture", "education", or similar well accepted aid activities, "private enterprise" tends to be treated as an orphan in a bureaucratic sense because in the traditional foreign aid programs which are usually administered on a government to government 
basis, there is almost no place to fit it in. Obviously, OPIC is not the answer for what we have in mind here.

Furthermore, since most efforts to help the private sector depend on the cooperation with private individuals rather than with government agencies, such programs cannot be as tightly controlled as for instance a project to improve a university where the hard nosed aspects of profit or loss do not enter into the picture. As a result, it is often felt that private enterprise programs carry a larger potential risk of criticism in case of failure which again tends to reduce their appeal at the working level to those engaged in administering foreign aid programs. Yet, the rewards to be derived from industrial development programs can be very considerable as demonstrated in a number of countries in the past, particularly in the Far East.

One of the biggest challenges facing the developing world in the decades ahead is industrialization. Increases in population, food production and mobility are going to create immense needs for jobs, improved income distribution and regional balance which require that a good deal more attention be paid to finding a proper way of industrialization. In spite of a growing emphasis on the development of public sector industry as a means to achieve specific, narrowly defined goals, experience has shown that the burden of successful industrialization in the developing world tends to fall largely on the private sector which, apart from the enactment of favorable policies for its further growth, often requires additional support in the form of incentives, credit and advisory services.

As the recent report of the National Academy of Sciences/National Academy of Engineering points out:

"Industrialization holds the prospect of increases in world income, employment, and trade which will benefit industrial as well as industrializing countries. Applied scientific research in agriculture has diminished (though not removed) the threat of famine for the two-fifths of the world's people who live at subsistence levels, providing a critical impetus to progress, worldwide. The Green Revolution is raising rural incomes and creating expanded 
markets for local and imported manufactures. But, it cannot in itself overcome the lack of productive jobs or raise wages to acceptable levels. "1

The case of Afghanistan is interesting in this respect because over a period of some fifty years, both approaches, involving development through the public as well as the private industrial sectors were tried, rejected and tried again. Here we have a country which in the $1930^{\prime} \mathrm{s}$ decided to pull itself up by its own bootstraps through policies favoring the private industrial sector for the simple reason that its Treasury was empty at a time when foreign aid had not as yet become fashionable. The success of this effort was almost entirely due to the drive and vision of the country's top political leaders as well as the remarkable foresight of a few unusual entrepreneurs who were able to mobilize domestic resources at a time when most nations in a similar stage of development were almost entirely subjected to colonial regimes. Another interesting aspect is that because of Afghanistan's closeness to the Soviet Union, these people had also become aware at an early date of the merits and drawbacks of economic planning. This in turn tended to influence their policies vis-a-vis the private sector in such a way as to find a compromise between the desires of the individual entrepreneur and the requirements of a developing nation. The outcome of this effort is described in Annex A. We believe it is well worth reading!

Some twenty years later, we find an almost total departure from this concept through the country's reliance on massive inputs of foreign aid. Such aid became possible largely because of the fact that during the cold war, Afghanistan's geographic location made it politically important to its two major donor nations, the United States and Russia. Afghanistan benefitted through a massive development of its infrastructure but at a price. While its original development phase had been carried out almost entirely "out of profits" with each new step being financed out of income created during the previous one, this next development phase placed considerable emphasis on comprehensive economic planning and the "guided economy" concept. Following this change in policy, the plans stressed the improvement of the country's infrastructure, supported by massive

1. National Academy of Sciences/National Academy of Engineering. Meeting the Challenge of Industrialization, A Feasibility Study for an International Industrialization Institute. Washington, D. C. , 1973, p. 3. 
inputs of aid from abroad. Ultimately, this resulted in a vast increase in the country's external debt, coupled with a minimum of political and human resources development or what we generally can lump together under the label "nation building". While one cannot and would not deny the merits of Afghanistan's effort to develop its infrastructure during its 1953-63 'break with the past", it is also true that this constituted largely a one sided effort in development for but not by the Afghans. Human motivation was conspicuously absent; compulsion was the word and a potential storehouse of private sector talent which could have complemented the development of the public sector and broadened the country's revenue base as a means for self-generating economic growth, was shunted aside into almost complete frustration or despair.

In essence, the development effort at that time consisted of heavy reliance on foreign technical assistance to draw up Five Year Plans including numerous projects, using the plans as a means to obtain a vast amount of foreign aid and writing a check to foreign contractors to do the job. Except for the unavoidable and substantial "slippage" in this type of operation, the results can easily be seen since brick and mortar tends to last more than a lifetime. The failure of a number of big public sector industries-largely because of deficient planning and the lack of competent managers to run them-which gradually became more and more of a drain on the budget is likewise clearly visible.

As a result, some ten years later, we note a gradual realization that much of this aid had been wasteful. This in turn led to a re-emphasis of policies favoring the private industrial sector and it almost provides a negative confirmation of the merits of the private sector approach, as discussed in this report.

Learning the hard way the nation discovered a few truths which have been summarized so well by Theodore Geiger ${ }^{1}$ as follows: (a) by relying more on private initiative, a nation can mobilize indigenous resources of money, skills and human energy that would not otherwise be available to it; (b) in developing their own industry, individuals tend to save more and work harder than they would for other purposes, in particular public sector employment; (c) in the initial stages of economic

1. Geiger, Theodore. Private Enterprise and Development, in "Dialogue, Vol. 4, 1971, No. 4, pp. 16-27. 
development, the private sector tends to reduce waste and inefficiency which the developing countries can ill afford. Particularly the allocation of resources within the particular industry has to be more judicious while the lack of managerial constraints tends to capitalize on the opportunities for diversification and innovation that arise in the process of economic growth; (d) a successful private sector tends to provide more productive employment than the public sector normally can. For instance, in India's small industries, management overhead is considerably smaller than if some of these industries were combined into larger units, partly because the individual entrepreneurs are satisfied with a relatively small return for their effort.

To sum it up, what Afghan officials perhaps grudgingly learned, is that in the early stages of economic development, the selfish interest of the entrepreneur often tends to coincide quite well with the attainment of national economic objectives in a true Ayn Rand fashion. ${ }^{1}$

Finally, after some six years of remarkable progress in the development of the private industrial sector, there was again a reaction in the form of increasing concern about "controls", "guidelines" and the promotion of public sector industry, which again affected the policies governing private sector development adversely. Thus, it would seem that the development of a private industrial sector in Afghanistan presents an interesting, almost unique, case study illustrating the position taken in our first paragraph.

\section{THE OVERALL SECTOR PROBLEM}

In a sense, the problem of economic and industrial development in Afghanistan is best stated in terms of the experience of King Amanullah who lost his throne by trying to do too much too fast in what remains essentially a tribal society. As Poullada points out, "the first and perhaps most obvious lesson to be learned from the Amanullah experience is that a tribal society tends to be extraordinarily resistant, and indeed hostile, to the unifying political discipline required for nation building". 2 Thus, what aid donors conceive as "logical" and are willing to pay for in order to eliminate gradually

1. Ayn Rand. The Virtue of Selfishness, New York, New American Library of World Literature Inc. 1964, passim.

2. Poullada, Leon B. Reform and Rebellion in Afghanistan 19191929, King Amanullah's Failure to Modernize a Tribal Society. Ithaca and London, Cornell University Press, 1973, p. 267. 
the country's dubious distinction of belonging to the "Club of the TwentyFive Least Developed Countries"'may well become obscured in a good deal of lip service, if not passive resistance if the need for it is not felt on a fairly broad basis.

For instance, as Dupree points out, "villagers willingly accept any all suggestions for technological change because they realize that the sooner they accept, the sooner the 'developers' will leave." 1 This unfortunate tendency is further aggravated by the fact that many dynamic foreign advisers, in their enthusiasm to get something done, have tended to "sell" programs to the Afghans which they actually believed would be effective but which were not conceived by the recipient as meeting an urgent need. As a result, the particular program started off on the wrong premise with the Afghans politely taking to the sidelines, rather than openly criticizing a project which frequently was offered to them without much of a commitment on their part.

Another problem, more specifically related to private industrial development, was that in Afghanistan, except for the merchants in the bazaar, there was no private enterprise tradition. As a matter of fact, except for its above mentioned change of heart forced by necessity, it can be said that in practice the government's day-to-day attitude of ten works out to be anti-business, particularly at the lower levels of administration. While risk taking, budding industrialists showed up in unprecedented numbers after the promulgation of the 1967 Foreign and Domestic Private Investment Law, there were at the same time many jealous lower echelon bureaucrats ready to deny them the rewards, Furthermore, industrial organizations, manufacturers' associations and labor unions were frowned upon as a potential counterbalance to almost unlimited government power.

Particularly during the first phase of the program, the traditional establishment, whose power was largely based on a military and feudal society, was often less than pleased to see "nobodies" rise up in industry, particularly if these nobodies turned out to be members of minority groups. Apart from that, there was ideological opposition from those who were committed to socialism or communism as well as from religious leaders who felt threatened by any departure from the existing traditional society.

1. Dupree, Louis. Afghanistan. Princeton, N. J., Princeton University Press, 1973, p, 249. 
Thus, it would seem that the first requirement of a successful development project in Afghanistan is that the local leaders perceive it as not encroaching on their particular power structure regardless of whether or not the project is in the national interest of political integration or merely resulting in domination by the central government. As pointed out above, the Private Enterprise Program faced some of these problems in that at times the program was felt as a threat by a minority of ultra conservative elements of the ruling oligarchy. The fact that they were easily overruled does not detract from the other fact that this resulted in some sort of insidious sabotage and protracted problems in the day-to-day execution of the program which called for unusual tact and perception on the part of the foreign advisers.

The easiest phases of the program were obviously the promotion of karakul fur exports which benefitted everybody, and tourism, although in the latter case ultra conservative elements of ten felt a threat to "their culture" because of the roaming around of too many tourists; the more difficult part was the development of a private industrial sector which, apart from affecting the traditional society, ultimately could result in a shift in income distribution and political power.

\section{PROJECT OBJECTIVES}

In the RFP ${ }^{1}$ for Atghanistan, dated October 1963, the Project was first proposed to "assist the Royal Government of Afghanistan through private enterprise to develop new industries for processing of agricultural products so that they are acceptable to move in the hard currency export trade and to increase production of commodities for local consumption in order to effect savings in foreign exchange." Subsequent CAPs of October 1964 and 1965 held to essentially the same rationale in defining the purpose for this Project. ${ }^{2}$

As time went by, these objectives became more broadly defined so that in the latter stages of the Project, the objectives were stated as follows: (a) to increase per capita income through the proper motivation and mobilization of the private industrial sector; (b) to help a group of private entrepreneurs become a driving force in modernizing the economy which in turn could lead ultimately to the creation of a more democratically

1. RFP abbreviated for Request for Proposals, CAP for Country Assistance Program.

2. See: Thomas H. Miner and Associates Inc. Afghanistan, Private Enterprise Program. Chicago, IIl. 1970, (mimeographed), p. II-1. 
oriented society, and (c) to increase the belief that economic and social advancement can be obtained through individual competence and effor $t$ rather than through preference based on influence, kinship, caste, social status or race. ${ }^{1}$

More narrowly defined the industries so created were to have a significant impact on rural income through the development of agribusinesses using domestic raw materials for export; simultaneously, there was an element of import substitution to be pursued in those cases where local industry would be able to compete with the imported product strictly on a cost and productivity basis. Equally important were the income distribution effects and the creation of an industrial labor force which in time would become more vocal in demanding those social changes without which real development cannot start. Obviously, in a country where labor is plentiful and capital is scarce, a conscious effort was made to use labor intensive technology to the extent possible.

\section{PROJECT PHASING}

The Project was carried out in two different phases or stages. Phase one (1964-70) was carried out under contract with Thomas H, Miner and Associates of Chicago which sent in a three-man team of high caliber generalists supplemented by specialists covering several sub-projects. During the first phase, the emphasis was on strengthening Afghanistan's balance of payments and developing a favorable investment climate in order to create as many new industries as possible with a general emphasis on agribusiness, export promotion and sensible import substitution.

The second phase (1970-73) was carried out under contract with Checchi and Company of Washington, D. C. During this phase, emphasis was placed increasingly on institutional development in support of the new industries as well as on the development of industrial policies designed to bring about self-generating growth.

The project's broad goals during the second phase, as stated in the PROP and the RFP were as follows:

Goal I. To further improve the investment climate and to increase reliance on indirect rather than direct controls.

1. See: USAID Non-Capital Project Paper (PROP) dated August 11, 1970. 
Goal II. To provide more technical support for existing small private industry through the provision of consulting services in the area of industrial extension.

Goal III. To help create better overall support facilities for private enterprise by acting as a catalyst or limited supporter in the creation of new sources of industrial and commercial credit, the enactment of better commercial legislation and in general, all those vital elements which normally operate in support of the private industrial sector but which are totally lacking in Afghanistan.

Goal IV. To provide the insights and information needed to guide the government in the development and implementation of industrial policy (Research) and to strengthen the indigenous private sector by providing a limited amount of training for people from local firms and institutions.

\section{HISTORICAL REVIEW OF THE PRIVATE ENTERPRISE PROJECT}

A. Phase One

1. The Major Project Components

a. Industrial Development

As pointed out, the mid 1960 change in government policy towards the private sector resulted from a combination of political developments and a growing disenchantment with the performance of government subsidized public sector industry. A subsequent consideration on the part of the government was the need to create more industrial jobs for a growing number of educated unemployed after it had decided to make a major effort in the area of university education.

A modest "Private Enterprise Program" was started in 1964 which originally was aimed at attracting the foreign investor through the preparation of a number of feasibility studies. After a considerable analytical effort, eight fields were selected for pre-investment feasibility studies. These fields included animal casings, sheepskins, cigarette manufacturing, corrugated boxes, spice and herb processing, carpet manufacturing, karakul processing, and tourism. Upon completion and 
approval by the government, each feasibility study was given a relatively wide promotion effort among potential American, European, and Japanese private investors as well as lending institutions.

By and large, this approach was unsuccessful. Therefore, in 1966 the direction of the program was changed radically. The new approach looked to the creation of a proper investment climate as a first requirement. Although such a climate would primarily attract indigenous investors rather than foreigners, it was assumed that if an attractive investment climate could be created and if the domestic investor would successfully move ahead, the foreign investor was likely to take note and follow. This assumption proved to be essentially correct.

Thus, during the first phase, the primary program goal was to get new private industries started. The goal sounds simple but in reality it was quite complicated. As a first requirement, it was necessary to create a proper legal base of operations which is so important in creating an investment climate. Once this was done, a handholding job was needed to guide the individual investor on how to avail himself of the benefits provided under the law. Because of the lack of an industrial history, the advisers had to work from scratch with each individual investor to get his projectstarted, most of whom had more money than ideas. The case of the first investor as discussed in Annex B provides a good example of the type of problems which had to be faced.

As part of the promotional effort, there was a need to create a rudimentary institutional base in support of the new industries. Thus, it became important to institutionalize the advisory services needed to get the investor started. Once this was done, an effort had to be made to find an adequate physical location for the new industries which initially sprung up in the midst of the residential area.

Obviously, this was a Herculean task for a small advisory team consisting of only three generalist senior advisors of Thomas H. Miner and Associates, in cooperation with four more advisers, provided by the Asia Foundation and Western European countries, who were either specialists in a certain industry such as food processing, or tanning, or industrial economists working at the junior level.

The first and formidable problem at the initiation of the first phase was that the lack of any tradition in creating a new private industrial 
sector. What little tradition was left from the 1930 's was taintedrightly or wrongly -by a connotation of "monopoly" or "exploitation". Many people doubted seriously that an entrepreneurial class could be developed in Afghanistan. Since during the period immediately preceding, most of the capital to establish new industries had been provided by the government, it was assumed that little or no savings would be available for indus trial investment.

Even the idea that businessmen would be able to engage in industrial activities not guided by the government was repugnant to many Afghans. Students in their second year at the University would timidly ask what was meant by the words private or public industrial sector while other intellectuals believed that the "warrier traditions" of the Afghans made them totally unfit to engage in this type of activity.

The matter of finding an administrative "home" for the newly emerging private industrial sector immediately became a problem. The seemingly "obvious" solution of locating the Program in the Ministry of Mines and Industries which had administered another "Private Investment Law" prior to 1967 was out of the question at that time since this Ministry was considered as the stronghold of the "guided economy" concept. Hence, no potential investor was likely to go near it. As the contractor pointed out in his final report:

"In the case of the Ministry of Mines \& Industry, the home of the 'guided economy' concept, the principal problem was that of guiding to such an extent that the project soon became a Government proposal being implemented with the investor's money. The Ministry of Mines and Industries regularly dictated capital requirements, machinery requirements, source of machinery, method of payment, type and quantity of production and any other detail which caught their fancy. Under these circumstances, only the hardiestinvestors

1. See: Thomas H. Miner and Associates, Inc. Afghanistan, Private Enterprise Program, Chicago, 1970, (mimeographed), p. III-1. 
persevered. This happened to a very large rayon weaving plant which was approved over four years ago and which only now is actually being implemented under the more relaxed atmosphere engendered by the Investment Program."1

Fortunately the alternative existed of having the program sponsored by the Ministry of Commerce which at the time was headed by Dr. Nour Ali who was a strong believer in the role of the private sector. Surrounded by a few other individuals who harbored the same philosophy. Dr. Nour Ali was able to lay down the fundamentals upon which a program could be built. Some of these concepts were completely revolutionary by Afghan standards, such as:

-It is the investor's money, He can spend it on manufacturing any item he likes, providing that he can prove reasonable feasibility, ${ }^{2}$ The corollary to this is that industrial investors are probably as smart as anybody else, at least, and stand in need of relatively little "guidance" by bureaucrats.

- The government is uninterested in where a man's capital comes from, or in what form, as long as it comes.

- The selection of partners is the investor's problemwhether he is foreign or Afghan. There are no imposed partners, nor quotas, nor "Afghan percentages".

- The purchase and selection of machinery, including second hand equipment if desired, is entirely up to the investor himself without any interference by bureaucrats who will not be responsible for the operation of the plant.

- The application basically consists of a feasibility study comprising all relevant information and projections for five years. This study, when approved, is the "license" as far as capital, imports, foreign personnel, etc. are concerned.

1. Miner. op. cit. p. III-2.

2. In practice, because of conditions in Afghanistan, this constituted a certain bias in favor of agribusiness oriented projects. 
- The project is considered by the government on the basis of the Application-Feasibility Study without further negotiation or "agreements".

- The letter of the 1967 Investment Law shall be the only guide and rule. An excess of zeal to foresee and prevent any possible abuse of Investment Law privileges is not to be used aB an excuse for bureaucratic harassment and interference in industry ${ }^{1}$

Thus, the basic elements of the first stage of the program were the enactment of the 1967 Foreign and Domestic Private Investment Law and the oreation of the related instiputions established to help implement the Law and to support the investors. All these are discussed in the subsections which follow.

(1) The Foreign and Domestic Private Investment Law

The legal base for the redirected private investment program which started in 1966, was the promulgation of a Foreign and Domestic Private Investment Law, early in $1967 .^{2}$ In addition to providing the usual incentives to the private investor, such as duty-free import privileges for equipment and raw materials, a five-year tax holiday, etc., this law established an Investment Committee composed of the Ministers of Commerce, Finance, Planning, Agriculture, and Mines and Industries. Approval of a proposed investment by this Committee, chaired by the Minister of Commerce, meant personal endorsement by five Ministers, and hence, relatively ready cooperation in implementing decisions by five Ministries. Also, this arrangement provided the new investor with a direct recourse to higher authority in case his effor ts were met with opposition from officials of the various key Ministries with which he would have to deal at one time or another.

What was important about the 1967 Private Investment Law was not so much its coming into effect-two private investment laws were on the books prior to 1967, namely, the Law Encouraging Industries under the Ministry of Mines and Industries, and the Foreign Investment Law

1. Miner. op. cit. p. III-7-8.

2. For a complete text of the Law, see Annex $\mathbf{C}$ of the Appendix. 
under the Ministry of Commerce-as the fact that it represented a change from investor control to investor support. ${ }^{1}$

Through the establishment of the Investment Committee, the 1967 Private Investment Law tried to provide actual support to potential investors and to eliminate many of the previous administrative difficulties. Since the previous investment laws were administered by two different Ministries, it was quite possible for one Ministry to block a project approved by another. These laws required private investors to negotiate what in effeot were highly specialized agreements with the government which governed all phases of their proposed operations. The stipulations embodied in these agreements included the form and amount of capitalization, type, price and suppliers of capital inputs, quality, and origin of raw materials, and the nature and amount of any technical assistance. The actual implementation of these agreements was often disastrous to the investor.

The 1967 Law, which was modified in 1974, changed all that. ${ }^{2}$ The key elements of the 1967 Foreign and Domestic Private Investment Law-apart from those mentioned above-consisted roughly of expanded fiscal benefits and guarantees on repatriation of profits and salaries to provide increased incentives for private investments, equal treatment for new investments, foreign and domestic, and greatly improved, clarified, and centralized procedures for the administration of the law and for the settlement of disputes.

The law provided benefits for approved new private investments, Afghan or foreign, in industry, mining, agriculture, tourism, or in any other service industry or priority enterprise designated by the Investment Committee (Article 2). It specifically provided that although all mineral deposits are owned by the State, the conclusion of individual agreements in the field of mineral exploitation or basic industry remained possible (Article 26).

1. For a review of the earlier investment laws, see: Nyberg, Howard. The Investment Climate of Afghanistan, An Analysis of Private Investment Laws and their Application, Kabul January 1966, (mimeographed).

2. Afghanistan, Ministry of Commerce. Foreign and Domestic Private Investment Law, Kabul, March 1967. 
following benefits:

In more specific terms, the law provided for the

-Exemption from taxes on company income for five years beginning with the date of first sale of products of the new investment (Article 3).

-Exemption from import duties on essential imports (machinery, raw and intermediate materials) for five yeats after the approval of the investments (Article 3).

- Tax exemption for interest on foreign loans which constituted part of an approved investment (Article 3).

-Exemption from export duties for ten years after approval of the investment (Article 3). Except in the above cases, foreign companfes and their employees were subject to the normal tax laws. The law stated that investments under this law were subject to an independent annual audit by auditors who meet international standards (Articles 10,11).

-Repatriation of profits, ospital, interest, salaries, royalties and approved fees was guaranteed within reasonable limitations and rules (Article 5, 6 and 9).

- Shareholders could freely dispose of shares, except that they were not allowed to sell to foreign governments. There was saving clause on this latter limitation to allow for subrogation under foreign governmental investment guarantees (Article 12).

-Joint ventures were explicitly encouraged, but the law did not require any specific percentage of domestic participation (Article 15). One hundred percent foreign-owned investments were not precluded. However, the law empowered the Investment Committee to negotiate sellback arrangements, among other things (Article 14).

The law required all government agencies and departments of the government to purchase their necessary supplies and services from enterprises established under this law, provided that these products were "substantially" competitive with imports (Article 16). 
The law included nothing more specific than the foregoing provisions with regard to protective trade measures available as incentives to investments. These, of course, were in no way precluded by the law, and protection of domestic industry subsequently became an established policy of the Government of Afghanistan, although not actually implemented because of the continuation of a defective tariff. Furthermore, the problem of policing Afghanistan's vast land frontiers is so great that there are limitations upon the government's ability to enforce protection through trade barriers and high import duties.

According to Article 17, rights of investors in the event of expropriation were re-affirmed by reference to Article 29 of the Afghan Constitution, which read, in part, as follows:

"Property is inviolable.

No one's property can be confiscated except in accordance with the provisions of the law and the decision of a competent court.

Expropriation is allowed only for securing public interest, against an advance equitable compensation, in accordance with the provision of the law."

The law made suitable provision for arbitration procedure, as well as for settlement according to the Convention of the Settlement of Investment Disputes between States and Nationals of other States, if the government and the foreign investor so agreed. Such an agreement could be reached either at the time of investment or when 2 dispute arose, as provided in the Convention. Afghanistan signed this Convention in September, 1966 (Article 19).

The "single license" provision (Article 24) establiehed that an inves tment finally approved by the Investment Committee would require no other license to operate in Afghanistan once such a license was obtained. The law provided, furthermore, that the controversial "Lioensing Regulations for Private Foreign Traders and Firms in Afghanistan" would not apply to investments approved under the new law (Article 25).

It remained government policy, nevertheless, to draw sharp distinctions between "foreign investors" and "foreign traders", 
and to attempt to separate the two types of activity as well as the rules applicable to them. Understandably, the law restricted enterprises approved for benefits under the Investment Law from exporting goods which they did not produce, or from importing goods other than those necessary for their own production or use (Article 24).

\section{(2) Supporting Institutions}

The Private Investment Law, valuable as it was, would not have been able to attract or promote new investment whout supporting institutions. Indeed, as noted above, the law itself provided for an Investment Committee and a "Secretary". However, it did not provide for a "Secretariat". To deal with the implementation problem, the first Chairman of the Investment Committee first tried to set up an "Advisory Sub-Committee" consisting of represfentatives of the Ministries of Mines and Industries, Planning and Commerce, together with the foreign advisors. The Sub-Committee was charged with project analysis, final recommendation for approval and the creation of procedures. It met only once but just long enough for the representative from the Ministry of Mines and Industries to make it clear that this Ministry would have nothing further to do with it. Taking another tack, the Chairman then established the "Investment Committee Secretariat" located in the Ministry of Commerce. Since most of the original investors emerged from the bazaar and since the Ministry of Commerce was already functioning as the "Registrar of Companies in Afghanistan" and was handling the issuance of trade licenses, the potential investors, mostly bazaar merchants, felt more at home in dealing with "their Ministry". With this, a rucimentary institutional base for the program was established.

As originally conceived, the principal function of the Secretariat was to make sure that new investment applications met the criteria established under the 1967 Private Investment Law, and to administer the law for approved applicants. This latter activity consisted mainly of processing invoices for duty-free importation of machinery, spare parts and raw materials, and handling administrative problems in connection with the export of finished goods.

Here a new problem emerged in that the Afghan officials in the Ministry of Commerce had no precedent in dealing with investors. But fortunately, of them had the right "non-dirigiste" philosophy so that 
over a period of time proper procedures could be worked out with the investors themselves. As the contractor puts it:

"Not surprisingly, once an investor (foreign or Afghan) is really sure that the Investment Committee means what it says, after two or three of his questiths have been answered with the statement "however you want to do it" or "as you wish" or "that's your decision, not ours, "then both the Secretary and the advisors are normally overwhelmed by pleas for help and guidance, together with assurances that their every suggestion will be followed to the letter. In short, once the investor is sure that nobody is trying to force anything on him, he then becomes voluntarily receptive to suggestions and even 'guidance'." 1

The second institution established in support of the program was the Investment Advisory Center (IAC) established in March 1969. Funded by the Chamber of Commerce, for several years technical assistance was provided to it by advisors from the United States, the Federal Republic of West Germany, Great Britain, France, and INIDO. Its functions included the preparation of investment applications for con $x$ sideration by the Investment Committee, in cooperation with the linvestors, performing market studies and other analytical work for the Committee, the statistical reporting on the program and a variety of industrial extension activities which were becoming increasingly important as the number of new industries increased. In contrast to the Investment Committee, the Center remained investor oriented i.e., primarily concerned with helping the investor.

From the beginning, the experience with the Center was somewhat mixed and for a while it existed in name only. It was felt that to gain confidence of the investors, organizationally the Center should be as far removed from the government as possible. About the only way to achieve this result was by locating the IAC within the Chamber of Commerce of Afghanistan. The Chamber is a peculiar institution since it forms a sort of a link between the government and the private commer-

1. Miner. op. cit. p. III-8. 
cial sector. Although the Chamber is composed of some thirty businessmen, its connection with the Ministry of Commerce is provided by a General President reporting to the Ministry of Commerce who controls its financial rësources which are generally derived from the collection of Hcense fees from commercial traders. Because the Chamber has its own budget, it has somewhat more flexibility in the use of $i$ ts funds than the Ministry of Commerce which worked out to the benefit of the IAC.

Once the administrative location of the IAC had been decided upon, a major battle ensued in finding a physical location for the Center which for a considerable time was located in two rooms in the Chamber of Commerce until finally the Ministry of Commerce made adequate space available to it.

Obtaining funding for the Center posed a considerable problem since the Chamber obviously considered the IAC as a stepchild and an unwelcome drain on its finances. The principal saving grace was, that fortunately bilateral and multilateral advisers were available to it free of charge which enabled the Center to get started with the work. However, here another problem loomed in that under the existing set-up it became almost impossible to obtain trainable Afghan counterparts largely because of the IAC's small budget and the lack of "glamour" attached to a semiofficial institution as compared to straight civil service status. Apart from this, to find candidates in Afghanistan who can be trained in the area of industrial extension is like finding the needle in the proverbial hay stack.

For all these reasons, the IAC as an Afghan institution never amounted to much during phase one of the program since during this phase most of the work was done by foreign specialists and relatively junior foreign advisers whose enthusiasm made up to a considerable degree for their lack of experience.

After the new Investment Law had proved to be successful in attracting new investments, the next logical step was to provide the investors with adequate industrial building sites since land for industrial purposes, complete with adequate water and power facilities, is extremely scarce in Kabul. To meet this problem, the government, in September 1969 , made available about 320 hectares for the establishment of an Industrial Park near Kabul. The tract of land provided for this purpose 
is ideally located in the Pul-1-Charkhi area on the way to Jalalabad. It is located near major highways and sub-surface water of good quality is available in adequate volume. Electric power is ample and sewerage facilities can be built at a reasonable cost.

To develop the infrastructure for this Park, the government initially intended to request a $\$ 1$ million loan from the Asian Development Bank. Partly because of difficulties in having such a loan approved by the Parliament as well as because the ever increasing problem of the external debt service, this idea was shelved in favor of using domestic financing which never was found. Thus, although a number of factories are actually located within the Industrial Park area, the creation of an Industrial Park and of an independent Industrial Park Authority is yet to materialize. However, thanks to a contribution of the government of India, a smaller industrial area has been developed within the original Park area.

By the time the first phase had been completed in late 1970 , remarkable results had been achieved. What nobody had expected, the effect of the Private nvestment Law was almost immediate. As soon as the potential investors realized that there was a "Court of Appeal" to which they could take their administrative problems encountered at the lower levels of the government, as well as competent advisors to help them in overcoming their difficulties, they began to file investment applications. Consequently, by December 31,1970 , some 130 investment applications had been approved, out of a total of 215 submitted. About twenty percent of these were export oriented while twenty-two were filed by foreign investors, many in partnerships with Afghans. Out of the above total number of investment applications, fifty-three new industrial establishments were actually in operation by the end of 1970 . This seems to prove that, given proper surroundings, Afghan businessmen appear to be eminently responsive to those incentives which seem to operate so well in other developing countries. Prior to 1967 , there had been doubts about this.

\section{b. Export Promotion - The Afghan Karakul Institute (AKI)}

In addition to its already expressed uneasiness about the budgetary implications of a growing but inefficient public industrial sector, in 1966 the government also became concerned about a decline in the karakul fur industry which for many years had been a major earner of hard currency. 
Efforts to remedy this situation again started as part of the Private Enterprise Program with full support from the U.S. Agency for International Development which provided contract assistance through the firms of Thomas H. Miner and Assdeiates and Vector Corporation both of Chicago, Hlinois. Thus, in July 1966, the Afghan Karakul Institute (AKI) was chartered by the Royal Government of Afghanistan, as the nation' first major independent, non-profit and privately financed, self-development program in agriculture and industry. ${ }^{1}$

Once established, the Institute's objectives were as fallows:

- To rebuild foreign buyer confidence in Afghan karakul.

- To develop an organization in Afghanistan which would unite the industry and through which all interests could participate in the industry's development.

- To create the financial resources necessary to support the industry's development and to use these resources judiciously.

out this plan effectively.

- To develop a long-range plan of improvement and to carry

In order to accomplish these objectives, the Institute adopted several basic operating policies, namely: (a) that the Institute had to be both independent and honest; (b) that it would have to share decision making with all its members and (c) that the Institute must communicate periodically with its members and engage in proper public relations activities at home and abroad.

Because of strong support on the part of the government, progress made in this area was relatively rapid. The Afghan Karakul Institute has grown continually in stature and by 1973 , it had become the country's leader for planning, developing, and coordinating the Afghan

1. For more details see: Vector Corporation. The Afghan Karakul Institute, Oak Brook, Illinois, May 1967, and:

Afghan Karakul Institute. Four Years of Progress in the Karakul Industry of Afghanitan. Kabul, August 1970. 
karakul industry. Due to better curing, dusting, sorting and grading of skins, the quality of the final product was upgraded significantly. From its start. the Afghan Karakul Institute had recognized this problem. To solve it, the Institute constructed a new sorting house in Kabul. It searched the country for the best sorters and graders and placed them on its payroll to assure independent judgment. The Institute also adopted strong policies to control sorting and it used all media to instruct exporters in the proper buying of skins. Equally important, the produce mix changed materially to seventy percent gray and thirty percent black, which greatly improved Afghanistan's competitive position with South Africa and Russia which produce mostly black karakul. Previously, in 1968 these percentages were almost reversed.

Considerable progress was made in the area of market orientation and market policies. At its start, the Afghan Karakul Institute had no authority to change Afghanistan's auction policies. Yet, informally, largely through difficult educational efforts, the Institute brought about significant changes in this area and public auction has now become the major means for selling Afghan karakul.

Likewise, good progress was made in the handling of buyer complaints. When the Institite started, Afghanistan had few men in the London and New York auctions who spoke English. Complaints, therefore, fell largely on deaf ears. Fur thermore, these representatives had no authority to act upon complaints and even if they did, there was no central organization in Afghanistan to whom they could turn for help. Fortunately, by 1973 , these problems had all been solved. The representatives in London and New York speak English; they are well schooled businessmen; they have the authority to act and the Institute exists as a central organization in Afghanistan to back them up.

As a result of these efforts, within only a few years, foreign exchange earnings from karakul increased from solne $\$ 9$ million in 1968 to about $\$ 17$ million in 1972 . In 1973 , there was a temporary decline because of severe drought conditions.

The average price of skins rose from $\$ 7.60$ in $1967 / 68$ to $\$ 14.16$ in 1973 , while quality skins were sold in the $\$ 16$ to $\$ 23$ range. It is interesting to note that the sharply increased income is largely due to better quality and preparation since the total number of skins sold in 
$1972 / 73$, was slightly lower than in $1967 / 68$. Although better world prices for karakul were evidently a factor, the point remains that because of its better organization, the AKI was able to take advantage of them.

Another interesting aspect of the project was that its impact was felt right down to the producer's level. AKI's flockowners education program and a program for broadening buyer competition have increased prices to flockowners from an average of Afs. 250 per skin in 1968 to Afs. 900 in 1973 , which is very significant from a point of view of income distribution at the grass roots level. Every year at lambing time the President of the AKI went on the radio to inform flockowners at what price their skins were being sold in the world market so that they would have a defense against unscrupulous buyers. Previously, they were totally in the dark about this.

Prior to the formation of the Institute, the exchange rate for karakul was Afs. 45 per dollar (as compared to a much higher free rate of exchange) which amounted to an export tax. Thanks to AKI lobbying, karakul was subsequently exported at the free rate of exchange. This tended to eliminate the smuggling of skins and provided greater benefits to the producer.

About one-thousand suppliers, most of them small operators, now deal through the Institute. Since the larger suppliers showed increasing interest in taking advantage of other investment opportunities in Afghanistan and were moving out of the karakul trade, this provides the smaller entrepreneurs with an opportunity to enter the trade through the use of the Institute's services.

The Institute was put on a sound financial basis and is now self-supporting. It receives $3 / 4$ of one percent of the gross proceeds of the sales in London and New York City, plus a fee of 1-1/2 Afghanis per pelt for sorting, grading, preparing for shipment, and arranging for shipping which altogether comes to a sizable annual income by Afghan standards.

The Afghan Karakul Institute was established as a nonprofit organization. The non-profit concept was adopted as a means for re-investing surplus funds back into the industry. Previous to the existence of the Institute, everyone was taking from the industry and returning very little. The Institute has re-invested very substartial

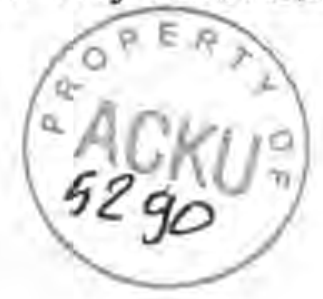


amounts back into the industry. To give only one example, $\$ 145,000$ was invested in the construction of a much needed sorting house. Located just out of Kabul, this building is now considered one of the finest in the world for the sorting and grading of furs.

It would seem that this sub-project also offers some interesting lessons from a point of view of project planning and methodology.

When the project was started, the timing was right. Declining karakul exports were becoming a matter of national concern. There was at least a commercial readiness, a realization that something had to be done and this accounted for getting the proper support from the government. Particularly, the support by the Minister of Commerce was crucial in the early days.

The use of proper counterparts constituted another factor. To find capable Afghans to spearhead a project of this type was not easy; yet it was essential if the project was to result in permanent success. Training was achieved in depth, allowing for several of the trainees to fall by the wayside. Honesty and integrity were stressed in the selection of potential candidates. As a result, for some five years, the project wound up with the right Afghan management, which was able to provide an element of stability.

To a large degree, the project was built on Afghan pride in achievement rather than holding out "bait" in providing technical assistance. Thus, financial remuneration became of secondary importance to those involved in the project, the ultimate success of which is largely due to the dedication and prolonged tenure-rare in Afghanistan-of Mr. A. G. Redja, the Institute's first President.

From the beginning, the U.S. technical assistance was well equipped to handle a project of this type with relatively limited resources. Altogether, about $\$ 180,000$ was spent for technical assistance, participant training and commodity support. The organization, marketing, advertising and public relations aspects were a natural for U.S. technical assistance. Where needed, additional assistance was sought from others, such as Hudson's Bay Company in London, which has a long history in the marketing of expensive furs. 
Another important factor was the way in which the project was phased out. At first, there were resident advisers. As the project progressed, these were gradually withdrawn, giving the Afghans a chance to go it alone and to learn from their own experience. However, to minimize possible mistakes, periodic advisor visits were arranged for so that mistakes could still be corrected in time. This approach went a long way in developing local pride and self-reliance.

Started as a grant, the project made a deliberate effort to provide the AKI with enough competence, as well as equity, in time to be able to apply for a loan for its future development. This virtually provided a built-in termination date for the technical assistance program.

\section{c. Promotion of Tourism}

Tourism looks like a growth industry in Afghanistan, since the country offers a most unusual package to the tourist. There are natural attractions of an incredible beauty such as the Hindu Kush mountain range and the unique lakes of Band-i-Amir contained by a natural wall several meters high. In the villages, there are patterns of living which have not changed for centuries. For those who love to rough it, there are most unusual opportunities in hunting and mountain climbing. To top it off, the country is endowed with most unusual archeological resources ranging from the early greaco Buddhist and Kushan times to the Islamic periods and beyond. Many of the country's ruins still await excavation. The great Buddhas carved into a cliff in the valley of Bamyan are unique insofar as the statues and their setting is concerned. Add to this a morning in the Kabul bazaar and a day in the old historical city of Herat and the tourist attraction becomes almost perfect.

The Private Enterprise Program made a relatively minor effort in the promotion of tourism, an area which was completely neglected during the early $1960^{\prime} \mathrm{s}$. Although this effort was limited to the preparation of an initial program for the development of the tourist industry, it constituted an important factor in drawing the government's attention further to a potentially very important source of foreign exchange income. ${ }^{1}$ Subsequent developments including the construction of an Intercontinental Hotel in Kabul provided ample justification of this initial effort.

1. See: Thomas H. Miner \& Associates Inc. Burvey of Tourism in Afghanistan. Chicago, ㄱll. 1965. 
All during the 1963-73 decade, the Afghan Tourist Organization and the private sector were able to capitalize effectively on the existence of these resources. As a result, the number of visitors entering Afghanistan with a tourist visa increased from 6,000 in 1960 to well over 120,000 in 1972. About half of these were Pakistanis while most of the remainder were low budget visitors from European countries. Of the arrivals by air, about 45 percent came from the U.S. and Canada, 27 percent from Japan and 16 percent from Europe. The average length of stay for groups of air passengers is about four days as compared to ten days for land travel. As a general observation, it can be said that the length of stay is in inverse proportion to the visitar' income bracket or per day expenditure. ${ }^{1}$

Income from tourism in 1972 was in excess of $\$ 10$ million. ${ }^{2}$ In 1973, the number of tourists declined somewhat but 1973 figures are not typical because of the July 1973 military Coup which caused a large number of people to change their plans. However, according to reliable estimates, ultimately the annual income from tourism could well reach some $\$ 20$ million a year. However, to reach such a figure would require a substantial investment in modern hotel facilities and related infrastructure. Because of the successes already achieved in this area, the;Worla Bank has shown considerable interest in providing financial and technical assistance to Afghanistan for the development of this potential resource.

\section{Significant Problems During the First Phase}

Right from the start, it was obvious that, apart from the usual administrative difficulties, a program of this type would be confronted with serious problems of socio-political nature. By Afghan standards, the program was almost revolutionary because it clashed with many values of a traditional society. It was obviously going to be opposed by those whose pocketbooks would be effected by it-i,e., a large group of politically powerful importers-as well as by those whose position would be made less secure by changes in social mobility, new life styles and a new attitude towards

1. Moyens Techniques et Projects. A Study of the Development of the Tourist Industry in Afghanistan. Paris-Kabul, 1972, pp. 307.2-307.6.

2. Kabul Times, August 15, 1973. 
authority i.e., the feudal aristocaracy. Leftist elements with a strong aversion to the private sector readily provided the ideological framework for attacks upon the program.

Initially these forces were more or less dormant for the simple reason that they did not believe that the program could or would succeed. However, as the number of industrial establishment and the number of workers increased and investors from abroad were beginning to come in, concern became more vocal. Instead of merely being frightening, the irreversable changes resulting from an industrial development program became an outright threat to the old ways of existence. Women were beginning to work alongside men, job promotion became based on merit rather than on family ties, and performance had to be related to results, a matter previously unheard of in the Afghan bureaucracy.

Almost simultaneously, the University was beginning to turn out vast numbers of graduates who could no longer be absorbed in the government bureaucracy as previously had been the case. This led to an increasing number of political demonstrations and merely added to the feeling of insecurity or outright fear on the part of the in-groups. The fact that they could no longer control the changes which could not possibly be reversed was disturbing in a society generally accustomed to tight controls from the top down. Memories of King Amanullah's attempts at forced social changes-as examplified by his efforts to free the women from the veil, contributing to his ultimate downfall-were still vivid.

Finally, the program was beginning to bring direct benefits to people who were relatively "unknown" by the standards of a feudal aristocracy, whose members were used to social and economic progress based on being known to and constituting no threat to the establishment. Quite a few of the new investors fell outside this category with merely making money becoming a criterion for success. The fact that they had a following, because of the number of people whom they employed, merely compounded the danger and was almost like creating new political party at a time when such parties were still not officially approved.

Another disturbing factor was that many of the new investors belonged to minority groups such as Uzbaks, Tajiks and Turkomen interspersed with a sprinkling of Hazaras whose rise was looked upon with a jaundiced eye. 
The first overt attack on the program was made in the spring of 1970 when the Afghan equivalent of the U.S. General Auditing Office accused the investors of illegal re-export of duty-free yarn to Pakistan. In a way their attack constituted an official recognition of the program as such since previously the people opposed to it would merely state that the factories did not exist or that they were merely a front for contraband trade activities.

At the time the target was the rayon textile industry which was accused of the re-export of duty-free yarn to Pakistan. The means was an official investigation which might be better described as harrassment and which included the seizure of books and documents from private factories, seizure and sequestration of raw materials, temporary seizure of the persons of the workers and their interrogation and temporary occupation of private textile mills by government officials. ${ }^{1}$ The attack and subsequent stoppage of operations resulted in great economic loss to the factories and some of the investors actually became discouraged, indicating that then and there they gave up their plans for further expansion. Although in the initial stage there were obviously some unscrupulous investors, the attack was a clearcut case of over-reaction. It had a distinct undertone of anti-private sector sentiment since some of the government investigators stated openly that private factories were not good for the country inasmuch as they tended to concentrate wealth in the hands of only a few families as had been the case in Pakistan.

The respective struggle, which even included direct insinuations against the Secretary of the Investment Committee, lasted for several months. After some of the charges had been thrown out in court and the then Minister of Commerce had thrown in his weight in favor of the investors, it began to subside culminating in a decision in favor of the investors by the Economic Ministers. Bureaucratically, the program had evidently arrived since it was found to be too valuable to be sacrificed in order to please the forces of traditionalism.

Another serious problem during the first phase was the fact that as the program took off, there was a deluge of investment applications and too few foreign experts to analyze their merits in depth. Initially this

1. See: Miner, op, cit. VII-5. 
proved to be no problem because most of the proposals for new industries were of the "obvious kind" i.e., to start new export industries based on locally available raw materials such as raw hides and grapes or else they were concerned with the most rudimentary aspects of import substitution such as developing a rayon textile industry to replace a sizable contraband traffic in imported rayon fabrics.

However, at the end of the first phase, some more complicated proposals were being presented which required an analysis in depth both from a point of view of the investors' chances for survival as well as from the national interest. To deal with these placed a heavy burden on the foreign advisers who in the absence of a competent Afghan staff frequently had to work sixty hours a week to keep up with the barrage of new applications. Hence, gradually the need was recognized to draw up a list of priorities for new industries which then led to the second phase of the program during which the emphasis was changed from helping individual investors to the development of more general industrial policies.

\section{Multilateral Aspects}

All through the Private Enterprise Program, there was a strong emphasis on multilateral co-operation and co-ordination with other institutions on the part of the USAID Mission and the U.S. private enterprise advisers. It was believed that such co-operation would give the program more stature in addition to reducing costs to the U.S. Government.

First there was a most important contribution made by the Asia Foundation which provided a legal expert to help draft the Private Investment Law. The Foundation did not stop at this; it also provided a food processing adviser who played a key role in the development of the raisin industry.

An important contribution was also made by the Hendrikson Group from West Germany which for several years provided a junior economic adviser to the IAC. A similar contribution was made by the French government while Great Britain supplied a textile expert for about one year.

UNIDO provided a leather and tanning expert as well as some non-descript short termers. The leather expert made a significant contribution to the success of the project. 
The Peace Corps also gave valuable assistance both to the AKI and the IAC by making available several volunteers specialized in accounting and management functions.

All through the program, an effort was made by the U.S. advisers to act as a catalyst for new activities which could subsequently be picked up by multilateral donors. For instance, in the case of the Industrial Park, the U. S. advisers tried to get the project sufficiently underway so that the government of Afghanistan could apply for a loan to the Asian Development Bank, to finance the execution of the project.

The same was true with respect to the establishment of the Industrial Development Bank to be discussed later. The U.S. advisers did considerable work in preparing the project to a point where a multilateral donor such as the U.N. D. P. or the IBRD could take over. Tourism is another case in point since the World Bank has become very much interested in providing assistance in this area.

In the case of the AKI, the U.S. advisers limited their efforts strictly to the marketing aspect with the understanding that the next stage i.e., improving the animal itself so as to get an even more saleable fur, would be diverted to another donor.

Particularly during the first phase, the "catalytic" effect of the program was quite significant since relatively small inputs of technical assistance were able to uncover either substantial domestic resources or else to lay the groundwork for subsequent multilateral support. This proved to be of great help during the second phase which will be discussed below.

\section{B. Phase Two}

1. The Major Project Components

\section{a. Industrial Policy Formulation}

Although the second phase of the program,carried out under an AID contract with Checchi and Company, constituted in many respects a continuation from phase one, there were important differences. As the number of industrial establishments increased from fifty three to about one hundred, it was obviously no longer possible nor desirable for the foreign advisers to play an operational role in the solution 
of the investors' problems vis-a-vis the various government offices. Hence, during the second phase, the emphasis shifted more to the conscious development of industrial policy and institutional development. The word "conscious" is important. Obviously during the first phase, the Investment Committee was faced with the necessity of making a number of decisions which over a period of time also resulted in the establishment of a certain, no matter how rudimentary, industrial policy. However, this "policy" involved mostly ad-hoc decisions.

In essence, the Committee's philosophy during the early days of the program was one of complete "laissez faire". Initially, this made sense since the Investment Committee was navigating in uncharted waters. For instance, when the first investor who proposed to build a steel re-rolling mill stated his need for importing steel billets, the Committee had to learn what billets were and it did so by carefully looking at one, (see Annex B of the Appendix). Even if it had wanted to do so, in the early days the Committee obviously lacked the capability of administering a Pakistani type of "sanctions" system for the approval of new industries.

As pointed out, initially the Committee did not believe in any controls or quotas since the idea was to attract as much investment as possible through providing a maximum degree of freedom to the individual investor. Only when things tended to get out of hand, did the Committee establish some limitations as was done in the case of the initial stampede to invest in the rayon textile industry based on the "follow the leader" principle. Thus, after a rough estimate of market demand, the Investment Committee decided in 1970 that no more applications for rayon textile mills would be approved until further notice.

As time went by, and gradually giving in to pressures from other quarters, the Investment Committee took it upon itself to consider new applications for private investment more in the light of national development objectives and began to think in terms of "priority needs". In a way, this constituted a departure from the general concept of the 1967 Private Investment Law which was merely concerned with ascertaining that the prospective investor would meet the legal requirements so as to be entitled to receive the privileges provided under the law. However, by international standards, the policy of the Afghan government still remained very liberal inasmuch no restrictions were put in the way of any investor who was willing 
to forego the benefits provided under the Foreign and Domestic Private Investment Law. Several investors actually preferred this avenue, feeling that the loss of certain benefits under the law was offset by their greater freedom from increasingly cumbersome government controls.

In stressing the development of industrial policy and the support of already existing industry, the second phase of the program concentrated mainly on four major areas, as follows:

- Improvement of the performance of the Investment Committee and particularly its Secretariat for the purpose of effecting gradually a shift from direct to indirect controls.

- Improving the Investment Climate by providing more technical support to prospective and existing private industry.

- Institutional Development, including the introduction of legislative changes in support of the private industrial sector.

- Research in support of all the three goals outlined above.

In trying to make progress under these four headings, the Contraetor, Checchi and Company, faced a most difficult task. While during the first phase spectacular results could be obtained because the program was practically starting from a zero base, during the second phase there was a need for much more detailed analytical work, argumentation and persuasion, which is clearly unglamorous and usually does not result in any kudos.

As additional investors filed applications for investment, the Investment Committee became more and more bogged down in details of which, by definition, it should not have taken cognizance. To give only one example, because of a defective import duty structure, the Investrment Committee, in passing on duty-free import privileges, became deeply involved in the day-to-day operations of the private investors.

All along, import duties on raw materials were so high, and on finished goods so low or, in some cases, reversed, that few industries could be established in Afghanistan without the relief from raw 
materials duties afforded by the Investment Law of 1967 or earlier legislation. Thus, virtually all non-government projects had to be handled by the Investment Committee. In this respect, Afghanistan was unique, or nearly so.

This situation gave rise to two related problems. First, the Investment Committee itself became deeply involved in nearly every project, which brought the predictable bureaucratic delays, inefficiencies and other problems. Secondly, since the Law provided duty-free raw materials for only five years, and few industries could continue to exist without such benefits after the fifth year, what would happen to those industries after the end of the five-year period?

The long-term solution to both problems was obviously a reform of the duty structure which would increase significantly the spread between duties on raw materials and those on related finished goods. This reform would open up numerous industrial opportunities which would require only limited Investment Committee action, i.e., basic approval for licensing and an income tax holiday. It would also make it relatively easy for approved firms to continue after the five-year duty-free period under the law was over.

The next important requirement was to improve the quality of the projects which came before the Investment Committee so that fewer questions of an analytical nature would arise. This was done through an effort to improve the planning and preliminary work on the part of the investors, the IAC staff and the advisers. The need for a more analytical project analysis and market studies can easily been seen from the fact that during the second phase, the investment proposals tended to become much more complex. In 1971, several larger projects were implemented such as the establishment of an oil blending plant, a soap factory and a pharmaceutical plant, almost all of which were constructed with substantial financial participation from abroad.

As the complexity of the later proposals increased, it became more and more difficult for the five Ministers to deal with the respective details in the Committee meetings. Hence, a Sub-Committee was appointed composed of lower level officials of the respective five Ministries to make "recommendations" to the Committee. Although the Sub-Committee lacked 
the necessary preparation and experience to do so in an effective manner, this at least put more pressure on the Investment Advisory Center for a more critical analysis of the proposed new projects.

Another problem was the fact that in view of the earlier described family loyalties, the Committee, in some cases,tended to overlook the negative recommendations made by the Investment Advisory Center and approve the project anyway. Obviously, this was hard on the IAC staff and the Checchi advisers.

Fortunately, there was a safety valve here. As long as Afghanistan was maintaining a free rate of exchange while at the same time the loose control of its borders threatened competition from abroad, the investor could not go very far in implementing a project which was basically unsound. Unless he was quite stubborn about implementing an unworkable project, all that could happen is that the project might not be of particular interest from a point of view of national development, a criterion which was not established in the investment law anyway. Fortunately, the approval of applications based on such a preferential treatment was limited.

To lend more legitimacy to the program, it became necessary to draw up industrial priorities for the private sector which subsequently could and were incorporated in the Fourth Five Year Plan. This again forced the Committee to think about industrial policy in a more abstract way rather than through incidental preferences or objections. Once it had been decided to do this, it automatically brought up the question of linkages between the Private Enterprise Program and its policies and the overall economic policy of the government.

To sum it up, although not always successful, the new industrial policy was designed to bring about a shift from direct to indirect controls. By doing so, the government tended to reduce and to some extent eliminate the role of a growing bureaucracy charged with the implementation of the Investment Law which generally was ill-prepared for this task. Furthermore, direct controls obviously tended to open the gates to corruption and favoritism which was exactly what the philosophy originally embodied in the Investment Law tried to eliminate. Thus, a conscious effort was made in automatically reducing some of the bureaucratic obstacles facing the investor by reducing the involvement of the bureaucracy itself. 


\section{b. Industrial Extension}

The second goal requires rela tively little explanation since the activity in question can largely be summarized as the provision of standard industrial extension services. Most of this was done through the strengthening of the capabilities of the Investment Advisory Center and by providing management assistance to it. While the lack of trainable Afghan counterparts remained a problem for a considerable period of time, gradually the IAC was able to develop some local competence in this area, thus correspondingly reducing the role of the foreign advisers.

A big step forward, in the summer of 1972 , was the government's decision to provide more adequate quarters to the Investment Advisory Center by locating it in the back of the Ministry of Commerce. The provision of some research materials and equipment by AID constituted another step in the right direction. Thus, gradually, although painfully slow by non-Afghan standards, the IAC began to develop a rudimentary capability to engage in market studies, in the preparation of periodic and special reports for the Investment Committee as well as in developing promotional material, such as an Investment Opportunity List composed of some twenty five industrial opportunities. 1 . This list was prepared to meet the needs of some investors who-while having the necessary funds and willingness to invest-had no clear ideas about what they wanted to invest in.

Last but not least, the IAC also started to develop its capability to provide direct technical assistance to actual investors although obviously in this area the main burden continued to be on the foreign advisers. As time went by, it more or less assumed the role of a rudimentary productivity center. In several instances, by introducing better methods and procedures, the foreign advisers to the Center were able to effect dramatic savings. To give only one example of the type of assistance rendered, by improving the moulds for plastic shoe manufacturing, a vast amount of labor correcting each shoe coming out of the defective mould could be eliminated. To the factory, this made almost the difference between a profit and a loss.

Participant training provided by multilateral agencies was important in getting the Afghan counterparts to the Center take over more

1. Afghanistan, Ministry of Commerce. Investment Advisory Center. Publication No. 2. Investment Opportunity List. Basic Data on Projects Which May Be Feasible for Afghanistan. Kabul, 1972. 
of the functions of the foreign advisers. Links were also sought with other institutions such as the Kabul University's Center for Engineering Consulting Services and Applied Research in order to draw upon capability already developed by other aid programs. Another important link was developed with the U.S. Peace Corps in the provision of accounting training, a most important service in view of the requirement in the Private Investment Law making the new industries subject to annual audits.

The Center also played an important role in developing industrial linkages, i,e., making the new factories work in support of each other. However, this could only be done towards the end of the project and after Mr. George Thomas, a U.S. direct hire industrial engineer had been added to the Mission staff. The acquisition of $\mathrm{Mr}$. Thomas by the Mission constitutes an interesting story in itself. From a point of view of project implementation, the type of services provided by $\mathbf{M r}$. Thomas were obviously needed for quite a long time. As a matter of fact, USAID had cohsidered requesting his services about two years earlier. However, doing so ran counter to AID/Washington's thinking about industry programs in general, which can be summarized in one sentence as follows: While we used to involve ourselves in industry programs years ago, we don't do this any more, the implication being that finally some of countries needing industrial development such as Korea or Taiwan had come of age and were able to go it alone.

Yet, the time frame of development is important since some countries such as Afghanistan are now at a stage where some of these other countries were years ago. Unfortunately, for the Club of the Twenty Five Least Developed Countries most of them woke up too late to benefit from AII's earlier largesse in this area!

Fortunately for the Program, Mr. Thomas' reputation was well known to some of the higher policy level officials of AID so that he finally did appear on the scene, Apart from making a dramatic effort in increasing industrial productivity, one of the first problems tackled by $\mathrm{Mr}$. Thomas was that of industrial linkages. The problem here was that because of the duty-free import privileges enjoyed by the new industries under the Investment Law, a tendency was gradually developing towards indiscriminate imports from abroad. By showing the investors that they could have certain parts or machinery made for them by other industries established under the program, without the need to wait for imports and at a lower cost, efficiency increased in the industries so 
affected while at the same time the supplier industries were able to reduce their idle capacity.

During the second phase of the program, a conscious and successful effort was also made to increase the Afghan contribution to the IAC's budget as well as to shift more and more of the functions of the Investment Committee Secretariat to the Center. At the start of the * program, the first step in filing an investment application was usually a discussion of the project between the prospective investor and the Secretary of the investment Committee. At that time, the Secretary explained the operation of the Private investment Law, discussed the yarious aspects of company formation, and checked if there were any other proposals similar to the one submitted. Depending on the case, at this point, there might have been also a discussion with the Minister of Commerce. The Secretary then prepared a letter to the Investment Advisory Center advising the IAC that initial approval had been granted and requesting that the Center assist the investor if necessary. 1

When the Investment Committee arbitrarily shifted from a "laissez faire" approach to requiring a project justification in national economic terms, it became obviously more government rather than investor oriented. Hence, the need occurred to provide the investor with some services which would be primarily concerned with his interest, in particularly the preparation of his investment application. This provided another rationale for removing the Center as far as possible from the government by placing it administratively under the Chamber of Commerce. As we shall see below, in the end it was not possible to maintain this stance since after June 1973 , the Investment Advisory Center was no longer allowed to exist as a separate organization but became part of the Ministry of Mines and Industries. ,

Because of the Investment Committee's concern with detail, the careful preparation of the investment application was very important to the future of the project. In the first instance, of course, the application, and related documents, were the basis for the Committee's consideration of the project. Equally important, however, was the fact that, once approved, the subsequent implementation of the project remained tied to the application. With regard to the duty-free importation of machinery and raw materials, the specific items and amounts which would be permitted were those shown in the application. Should the applicant underestimate his requirements, he -would be expected to pay duty on the excess unless his application was amended or, for small amounts, unless specific approval of the Minister of Commerce was obtained. In case the investor had no specific investment idea but had money to invest, a relatively frequent occurrence, the staff and the foreign

1. For more details on the initial procedures, see: Zondag, C.H. Private Industrial Investment in Afghanistan. USAID, Kabul,1971, passim. 
advisers at the Center usually explored the various possibilities with the investor and assisted him in preparing his application.

In theory, the IAC's analysis was concerned with such items as: technical analysis, cost of machinery and raw materials, operating costs, market information, personnel requirements and how they would be met, foreign exchange implications, sources of financing, import requirements, etc., but in practice, in most cases it still lacked the capability to do so unless assistance was provided by the foreign advisers.

\section{c. Institutional Development}

In the area of new institutional development, two achievements stand out during the second phase. In both of these, the U.S. contract advisers played a major role. The first was the creation of an Association of Private Investors capable of representing the interests of the new industrialists vis-a-vis the government. Originaliy, the Mission's Private Enterprise Division intended to achieve this result through conducting a management seminar for the more prominent private investors in the hope that this would also bring them together to form an Association. However, the association developed spontaneously after the Checchi Team had put in a considerable effort in helping the investors to organize an industrial exhibit during the spring of 1972 where thirty five of the new factories displayed their products to the public. This led to the subsequent formation of an "Afghan Association of Private Industries" composed initially of some 65 members. Apparently, the investors, in talking to each other, discovered that they had a lot of problems in common and that jointly they could present a better case to the government than by doing so in isolation.

The government's reaction to the group was initially cautious. Still fearful of labor unions and other political organizations, it objected to their initial proposal of calling the new group a "Union of Manufacturers". However, it approved them subsequently as an Association".

Again, such a development may not mean much in other countries but in Afghanistan where only a few years earlier individual investors were almost afraid to present their complaints to the Ministries in a forcefuI manner, this meant a lot. If anything, the Association set up a channel of formal communication between the investors and government. As the latter gradually became more aware of the benefits of the program in terms of contributions to employment and foreign exchange earnings and savings, it began to listen more attentively to the investors. Above all, the Association 
became an important tool in coordinating the national industrial development goals as expressed in the Fourth Five Year Plan with the interest of the private investors.

Another important accomplishment in the area of institutional development was the establishment of an Industrial Development Bank in the spring of 1973. Here again, the role of the Contractor, Checchi and Company, was erucial inasmuch it filled the gap created by the departure of the Nathan Team ${ }^{1}$ which had nurtured the project for a number of years. Thus, in 1972, one of the Checchi advisers was asked by the government to become the principal coordinator for the establishment of the Bank. In that role he worked closely with a World Bank Mission which visited Afghanistan in July 1972 to straighten out many details regarding the establishment of the Industrial Development Bank. The adviser also prepared a number of key documents including a detailed description of the proposed Bank and its operations, its Articles of Incorporation and other special papers. Because of the obvious lack of Afghan competence in this area, the adviser's role was crucial in getting the project started. ${ }^{2}$

The history of this institution is likewise enlightening. 3 The establishment of an Industrial Development Bank had first been discussed some ten years earlier but right from the start it ran into difficulties. In general, these difficulties centered around the question as to whether the Bank should be private or public in character. Some people were opposed to the concept itself, expressing the fear that such a bank would tend to favor only a small group of people who as the result of the loans obtained would be able to accumulate considerable wealth as had been the case with the twenty millionaire families who emerged in Pakistan during the regime of President Ayoub Khan. From a political point of view, distributing the poverty was obviously more acceptable than

1. Robert R. Nathan and Associates, Inc. of Washington, D. C. maintained an economic planning team in Afghanistan for a number of years.

2. For more details, see: Checchi and Company. Fourth SemiAnnual Report January-June 1973.

3. For more details, see: History and Status of the Proposed Industrial Development Bank of Afghanistan, USAID, Kabul, 197.2, (mimeographed). 
creating wealth, even if the need for more industrial jobs was at the same time proclaimed as a national objective of relatively high priority.

When assistance was requested,in 1966, from the International Finance Corporation (IFC), a World Bank affiliate, in order to establish such a bank, the project ran again into trouble because the IFC appeared to be reluctant to move until the promulgation of a new private investment law. The IFC was clearly concerned about the investment climate in Afghanistan as it existed at the time. It also insisted on a large participation in the Bank by Afghan private investors.

An additional hurdle had to be overcome in the form of establishing a proper legal base for the establishment of the Bank. To get the respective law approved by the Parliament required extensive maneuvering. Actual approval did not materialize until in August 1971, the King threw his weight behind it although as early as $1967 \mathrm{a}$ draft law to establish the Industrial Bank had been approved by the Cabinet. Thus, it took until 1973 for the Industrial Bank to become a reality.

As presently constituted, the Bank's total equity is Afs. 240 million of which forty percent or Afs. 96 million was subscribed by a number of foreign banks and the International Finance Corporation. The group of foreign banks is composed of the Chase Manhattan Overseas Banking Corporation, the First National City Overseas Investment Corporation, the Industrial Bank of Japan Ltd., the National Westminister Bank Ltd. and the Credit Lyonnais. Afghan shareholders contributed the remaining sixty percent of the equity or Afs, 144 million. The Banke Millie Afghan, the Chambers of Commerce of Afghanistan and the Pashtany Tejaraty Bank are the largest Afghan shareholders, having nearly 100, 000 shares among them. The remaining shares are held by about 160 private Afghan businesses and individual investors.

In addition to its equity capital of Afs. 240 million, the Bank received a commitment for an Afs. 560 million loan from the Government of Afghanistan. The institution 2 lso obtained a $\$ 2$ million line of credit from the International Development Association (IDA), designed to cover its hard currency requirements for about two years. After that time, it is understood that additional IDA funds would be made availdble to meet the Bank's further needs. During its first five years of 
operation, the Bank was to be supported by a three-man foreign management team, funded by the U.N.D.P. with the World Bank acting as executing agency.

\section{d. Research}

Because of the need to develop more adequate industrial policies, a greater effort in research was necessary to properly define such policies. As pointed out,initially these efforts were focussed on a revision of the tariff to make it more development rather than revenue oriented. ${ }^{1}$ In a subsequent stage the research effort was directed to tying the promotion of industrial development in with other national goals such as the development of additional agribusiness ventures for export. Another research thrust was made in the direction of the geographic diversification of industry in order to diminish the concentration of industry in the Kabul area.

In spite of many difficulties, by the middle of 1973 , the new private industries were well established. As a matter of fact, by that time the program had become too large to be administered by the Ministry of Commerce. Hence, for the sake of a better coordination between all industries, both private and public, a decision was reached in June 1973 to transfer the control over the Private Enterprise Program from the Ministry of Commerce to the Ministry of Mines and Industries which gradually had lost its initial hostile attitude to it.

Consequently, a separate division was created in the Ministry of Mines and Industries consisting of two general directorates, one to handle investment applications, surveys and technical assistance, i.e., comprising all of the investor oriented functions previously handled by the Investment Advisory Center, and one which would continue to handle the work which formerly was the province of the Secretariat of the Investment Committee.

The loss of having the old IAC operating at some arms length from the government was compensated in part by a much larger financial contribution from the Ministry of Mines and Industries, and a more positive attitude by the latter Ministry to private investment in general. In addition,

1. For more details see: Checchi and Company. Afghanistan, Recommended Revised Custom Tariff Based on SITC Codes, Kabul, April 1973. 
a Planning and Pclicy Board was created for the development of industrial policy and to create a better coordination between the private and the public industrial sectors.

After the fall of the Monarchy in July 1973, the government's interest in industrial development was confirmed by the President of the Republic who made the following statements in his inaugural address:

"The Republican State of Afghanistan attaches great importance to heavy industries, such as extraction of mines, and metal and machine building industries, chemical industries and electric power, which insure rapid economic growth and consolidation of the independence of the country; serious steps are envisaged to be taken in this sector of the economy. Exploitation of the Hajigak iron ore for setting up a smelting mill and industrialization of the country is our long cherished wish.

The Republican State will encourage, protect and guide and control private investment and private enterprise in the field of light and medium industries as well as handicrafts, and necessary cooperation will be insured between the private and state capitals for progress, coordination and balanced economic growth.

The Republican State considers the protection of national industries and handicrafts as well as national arts its paramount duty, and will adopt a policy of protection for home industries and commercial enterprises against the competing foreign products and capital. "1

While this statement is obviously a reconfirmation of the guided-mixed industrial development concept, it also reflects the government's recognition of the new private industrial sector. To put it in one sentence, what the government had in mind was that the private industrial sector would be given strong support and protection provided its activities were in line with the national interest as outlined in the Fourth Five Year Plan.

1. Kabul Times, August 26, 1973. 


\section{The Mining Sector}

On various occasions, the government expressed interest in mineral development as part of its Private Enterprise Program because the Foreign and Domestic Private Investment Law included a clause on mineral development. As may be noted from the Appendix, Article 26 of the 1967 Private Investment Law specifically mentioned the possibility of private investment, either domestic or foreign, in minerals exploration and exploitation.

Such an interest made sense because as may be noted from Annex D of the Appendix, Afghanistan's mineral potential is promising.

Although the subject was tabled on several occasions, mainly in terms of the possibility of AID providing technical assistance in the drafting of a proper mining and petroleum code, nothing much was accomplished in this area mainly because of the government's lack of familiarity with this area. While private sector mineral development, including foreign investment, was considered desirable by the government as a means to increase foreign exchange earnings and to provide employment outside the cities, there was at the same time a strong fear that, because of its inexperience, the government might be taken advantage of by foreign companies. Hence, there was a tendency to give preference to "experimenting first with one or two small concessions" rather than taking the plunge and enact an attractive mining or petroleum code which would provide equal opportunity to all investors. Another problem was that getting such legislation passed by the Parliament, presented almost unsurmountable problems.

Nevertheless, after the 1973 Coup d' Etat which eliminated the Parliament, the Checchi advisers did become involved in a review of a proposal by the Cie. Francaise des Petroles for the exploration and exploitation of the country's petroleum resources. This included comments on a draft petroleum code prepared by a former Deputy Minister of Mines and Industries, Mr. Abdul Quddus Majid. The ultimate outcome of these negotiations is still uncertain at this time. 


\section{Significant Problems During the Second Phase}

As the program expanded, its problems, naturally, became more complex. One of the principal problems was that as the government began to look at the private industrial sector more from a point of view of its contribution to the national economy, the need for a clear industrial policy became even more apparent. The fact that many of these decisions were still made on ad-hoc basis, contributed to a certain uneasiness on the part of the investors.

In a number of cases, cumbersome procedures and delays in decision making resulted in the investor losing a great deal of time and money. Failure to implement the Investment Law in specific cases such as compliance with the requirement of Article 16 of the 1967 Investment. Law-which stated that once local industry produced a product equal in price and quality to the imported one, all government agencies would have to purchase the domestic product-resulted in a considerable excess capacity and caused additional hardship.

As a result, early in 1973 , the investment climate began to deteriorate and many potential investors, especially those from abroad, took to the sidelines. The problem was further complicated by the fact that the general tension between India and Pakistan, eulminating in the secession of Bangladesh and the resulting tighter control of the Pakistan border, made exports, either legal or illegal, of Afghan products more difficult.

Another problem was that in spite of the establishment of the Afghan Association of Private Industries, the effective communication between this group and the government still left much to be desired. Furthermore, the inability of the Ministry of Commerce to handle a large program of this kind resulted in an increasingly weak support for the private industrial sector. Thus, good opportunities in mining and tourism were missed as a result of the general incertainty.

As pointed out, the transfer of the Program in 1973 from the Ministry of Commerce to the Ministry of Mines and Industries was a mixed blessing. However, since this change was superceded by the July 1973 Coup d' Etat, it did not have a serious effect on program implementation except for making the procedures more bureaucratic. 
While these negative factors were serious and in some cases quite damaging, they were offset in part by favorable developments such as the establishment of the Industrial Bank and a gradual realization on the part of the government that if the private sector were to continue making a significant contribution, a drastic and more positive change of attitude toward the program would be required.

After the 1973 Coup, the Private Enterprise Program remained in limbo for a number of months, because obviously the government had more urgent matters to attend to. Thus, for some eleven months, no new investment applications were dealt with in a responsable manner by the Investment Committee and decisions on vital matters affecting the program delayed. Yet, it is interesting to note that during the second half of 1973 , i. e., after the Coup, five new factories opened their doors, ore of them quite large and with a substantial participation from abroad.

As conditions became more normal, the government turned its attention to the proposed amendments in the 1967 Private Investment Law and a revision of the tariff. Such amendments were highly desirable because the Dari text of the 1967 Law was quite ambiguous on a number of points. However, once in the act, the government "over-amended" by making some more drastic changes and promulgating a new Private Investment Law, now quoted as the Foreign and Domestic Private Investment Law of 1974. Annex C of the Appendix shows the text of the old and the new laws side by side.

The initial reaction to the new law, particularly of the foreign investors, was quite unfavorable. However, as pointed out above, the new law has some good points inasmuch it clarifies ambiguities under the old law and eliminates certain, presumably, favorable aspects which, although written in the old law such as Article 26 on mineral exploitation, were not being implemented anyway.

The major improvements in the new Investment Law are: (1) a removal of the time limit on duty-free importation of capital goods (was five years) and duty-free export of products (was ten years); (2) a provision for somewhat improved benefits for projects located outside of Kabul province, to encourage dispersion of industry; (3) a listing of the bases for approving projects, which should help establish priorities; (4) a minor strengthening of the clause requiring government to favor local suppliers, and (5) a strengthened requirement regarding auditing. 
From an administrative aspect, another favorable change was that almost simultaneously with the promulgation of the new Investment Law, the Private Enterprise Program was transferred from the Ministry of Mines and Industries to the Ministry of Planning. Apart from the fact that the latter Ministry has been gaining in stature since the establishment of the Republic, it also provides a better vehicle for coordination which is important in implementing agribusiness projects, requiring the involvement of several Ministries.

The major unfavorable features of the new law are: (1) a requirement that all projects have at least 51 percent Afghan equity participation; (2) a shift from duty-free raw materials to an arrangement whereby individual duties for approved projects will be set annually for individual raw materials; (3) a reduction from five to four years of the tax holiday, and a number of other minor reductions in the extent of benefits; (4) increased emphasis on control rather than promotion in a number of areas, and (5) a provision which makes the law retroactive to all projects previously approved in the sense that, once the law is published in the Official Gazette, the former projects must conform to the new law. This retroactivity provision, understandably, is most opposed by existing enterprises, especially foreign.

During the several months that the law was under discussion, the USAID Private Enterprise advisers prepared complete proposed drafts and, on request, many other proposals on specific sections of the law. However, the advisers did not participate directly in the special committee, the Investment Committee or Cabinet deliberations. The final result is, in many respects, different from what the advisers recommended and hoped for.

\section{VL. RESULTS}

By June 30,1974 , one-hundred ${ }^{1}$ new industrial establishments representing an investment of Afs. 1.2 billion had been established under the provisions of the 1967 Private Investment Law. ${ }^{2}$ Considering the different exchange rates in effect during the period, this investment comes to about $\$ 15$ million equivalent. Since the Industrial Bank had not

1. For a detailed list of all the establishments, see Annex E of the Appendix.

2. Source: Ministry of Planning. The Investment Committee of Afghanistan. 
as yet made any loans prior to 1974 , almost all of this capital was mobilized without the benefit of any industrial financing.

By June 30, 1974, a total of 260 investment applications had been submitted to the Investment Committee, excluding nineteen which had been superseded by applications for modification or expansion. Of these, 210 had been approved; only twenty-seven were rejected. The balance was pending final Committee action. Seventeen industries had stopped production for various reasons; seven only temporarily, while twenty were under construction and expected to start operating in the very near future. The total employment created by these new industries came to about 7,000 jobs, most of them for semi-skilled workers.

A breakdown of the new industrial establishments by major fields of activity and geographic location is shown in the tables on the next two pages. As may be noted, most of the new industries (82) were located in Kabul. Six were located in Kandahar, four in Jalalabad, three in Mazar-i-Sharif and one in Aqcha. Four more were located in Herat and Charikar. This clearly reflects the difficulty of establishing industry outside of Kabul because of the lack of power and infrastructural facilities.

Of the total investment of some Afs. 1.2 billion about three quarters represented domestic investment; only about one-fourth was foreign, either one-hundred percent or in combination with Afghans but these generally represented the largest investments. West German investment accounted for the largest share because of the $\$ 2$ million investment in the Hoechst pharmaceutical plant. The capital of the others was Pakistani (6\%), American or Swiss (about $3 \%$ each) and British, Indian, Turkish, Italian or Iranian (about one percent or less each).

What is particularly gratifying is the relatively high percentage of new industries-about thirty percent-which are export-oriented. Another interesting aspect is that as a revived private industrial sector expanded, it began to concentrate on the creation of clusters of new industries of national importance such as textiles, leather and tanning or raisin processing for export. Industrial linkages developed between the various plants supplying each other, thus reducing the need for imports.

For instance, in the rayon textile weaving field, 18 firms were operating in 1974 . Some Afs. 240 million had been invested in these 
(Total inyestment, nationality and geographic location)

(All figures rounded)

\begin{tabular}{|c|c|c|c|c|c|c|c|c|c|c|}
\hline Type of Project & Total & & \multicolumn{3}{|c|}{ Export Oriented } & \multicolumn{4}{|c|}{$\begin{array}{c}\text { Partially } 1 \\
\text { Export Oriented } \\
\end{array}$} & $\begin{array}{l}\text { Domestic } \\
\text { Oriented } \\
\end{array}$ \\
\hline Number of projects & 100 & & & 28 & & & 1 & & & 64 \\
\hline $\begin{array}{l}\text { Estimated investment } \\
\text { (millions of Afs) }\end{array}$ & 1,204 & & & 236 & & & 10 & & & 864 \\
\hline Percent of investment & $100 \%$ & & & $20 \%$ & & & 99 & & & $71 \%$ \\
\hline Geographic Location & Kabul & Jala] & abad & Ma: & & Kandahar & Her: & & Charikar & Aqcha \\
\hline Number of projects & 82 & & 4 & & & 6 & 2 & & 2 & 1 \\
\hline $\begin{array}{l}\text { Estimated investment } \\
\text { (millions of Afs) }\end{array}$ & 1,037 & & & 1 & & 41 & 27 & & 15 & 20 \\
\hline Percent of investment & $87 \%$ & 4 & & 19 & & $3 \%$ & $2 \%$ & & $1 \%$ & $2 \%$ \\
\hline Nationality of Investment ${ }^{3}$ & Afghan & Pak. & Ind. & USA & UK & Germany & Swiss & $\underline{\text { Italy }}$ & Iran & Turkey \\
\hline Number of projects ${ }^{4}$ & 92 & 7 & 3 & 3 & 2 & 2 & 1 & 1 & 1 & 1 \\
\hline $\begin{array}{l}\text { Estimated investment } \\
\text { (millions of Afs) }\end{array}$ & 892 & 69 & 10 & 38 & 15 & 128 & 35 & 5 & 2 & 10 \\
\hline Percent of investment & $75 \%$ & $6 \%$ & $1 \%$ & $3 \%$ & $1 \%$ & $11 \%$ & $3 \%$ & & $1 \%$ & $1 \%$ \\
\hline
\end{tabular}

1. Projects which sell much of their output to foreigners. This is economically the same as exporting.

2. Excluding IDBA, Hayat, Akbary and projects under construction. Includes Afs. 15 million for AHU under exports.

3. According to applications.

4. Projects with any percentage of foreign investment are counted under the foreign country as well as Afghanistan. Therefore, the total exceeds 100 (is 113). For investment, the percentage is used, so the total equals Afs. 1, 204 million.

Source: Investment Committee of Afghanistan. 
(By type of activity)

\section{Oriented Towards Domestic Market}

\section{Export Oriented}

Animal casings ${ }^{2}$

Raisin processing

Leather and tanning ${ }^{2}$

Honey processing

Bone meal

Fur raising and processing

Wine making

Nut processing

Total

\section{Partially Export ${ }^{1}$ Oriented}

Dry cleaning

Sausage mfg.

Cardboard containers

Coca Cola/Fanta

Total
Data processing

Rayon weaving 4

Rayon spinning

Knitted goods

Steel re-rolling

Printing

Edible oil

Metal Fabricating (furniture,

bus bodies, etc.)

Plastic products, (bags)

Plastic footwear

Building tiles

Soap

Detergents

Lubricants blending

Paint, insecticides

Pharmaceuticals

Ice plants

Foam rubber/mattresses

Leather shoes 5

Storage batteries

Accounting

Development Bank

Total

\section{8}

1

2

3

1

7

5 for export.

5. The largest of these, AHU, exports some processed skins as well.

Source: Investment Committee of Afghanistan 
plants, based on relatively conservative estimates. By the middle of 1974, they employed some 2, 400 workers and had in operation close to 1,100 looms. Their combined total capacity, working full time, and under ideal conditions, would be between 22-25 million meters a year. Actually it was about thirty percent less. In national economic terms, the elimination of rayon textile imports, because of local manufacturing, saved the nation about $\$ 2$ million in foreign exchange in 1972 .

Although some of these textile milis are very small and inefficient, the fact remains that they measurably increased the number of looms in the country which is still short of meeting both the current domestic and export demand. By combining forces, they could establish a third major textile industry complex in addition to the larger mills already established. By exporting cotton grey cloth instead of exporting ginned cotton or cotton yarn, Afghanistan could easily increase its foreign exchange receipts by about $\$ 10$ million a year. The small private mills could either switch to cotton or else continue to produce rayon fabrics, leaving the larger mills the possibility of concentrating on cotton rather than producing rayon cloth for domestic consumption. It would seem that sufficient flexibility exists to achieve the desirable result of increasing exports.

The tanning and leather industry presents a similar case. In 1973 , there were some ten ${ }^{1}$ firms engaged in this activity operating under the protection of the 1967 Private Investment Law and representing an investment of some Afs. $120^{2}$ million. Together they employed about $500^{2}$ workers. What seems significant is that tanning and leather processing in Afghanistan is now beginning to develop into a national industry. Due to the world-wide leather shortage, the private investors have all the markets they can handle. If they are able to meet the proper standards to respond to this demand, leather processing could well develop into a new Afghan export industry of major importance. This potential is corroborated by the fact that recently a large U.S. leather firm joined hands with an Afghan tannery to produce quality skins for export.

1. Including AHU Shoe which also produces leather shoes and is usually counted in that category.

2. Including the portion of AHU Shoe devoted to tanning. 
Apart from these "statistical" results, there was the institutional development mentioned above resulting in the creation of five important supporting institutions. Last but not least, the development of industrial development policy with the assistance of the foreign advisers, was crucial to support a rapidly growing private industrial sector. To give only one example, once the five-year duty-free period under the Law ran out, the investors found themselves faced with a tariff structure which historically placed a lower duty on the finished product than on the raw material required to manufacture it locally. As a result, a new tariff had to be developed, making it development rather than revenue oriented. A great deal of effort was expended on this effort and, at the moment, it seems to be bearing fruit.

\section{SOCIO-POLITICAL BENEFITS}

Less tangible are the socio-political benefits which are important because of their nation building implications; yet, they are clearly present inasmuch as industrial development of the type described can be important in bringing about much needed changes in a traditional society. The need for this is obvious for a lack of socio-political development constitutes one of the main reasons why Afghanistan, in spite of substantial economic assistance over a period of many years, today still continues to be an unhappy member of the Club of the Twenty-Five Least Developed Nations.

Unfortunately, because of the lack of electric power in other areas, the program's impact to date has been concentrated mainly the Kabul area. Yet, in a city of some 500,000 people, the socio-economic impact of these new industrial establishments giving employment to some 7,000 workers or about twenty percent of the industrial labor force, becomes quite noticeable, both from a point of view of the visible skyline and because of its emergence as a political force. The case will become much more dramatic when the number of new private industrial establishments reaches around two-hundred with a payroll of some 15,000 which may still be several years off. Finally, if one accepts the thesis that, above all, development is a state of mind, the following facts would seem to be highly significant:

- Five years ago, an investor with sizeable capital would have lived in constant fear of a government official earning Afs. 2, 500 a month,

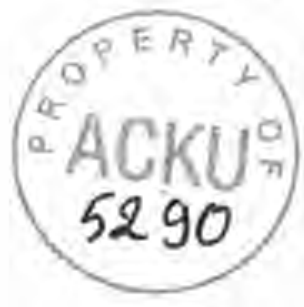

